\title{
Pengaruh Lingkungan Kerja Terhadap Kinerja Karyawan
}

\author{
Lyta Lestary ${ }^{*}$ dan Harmon ${ }^{2}$ \\ ${ }^{1}$ Jurusan Administrasi Niaga, Politeknik Negeri Bandung, Indonesia \\ ${ }^{2}$ Jurusan Administrasi Niaga, Politeknik Negeri Bandung, Indonesia
}

\begin{abstract}
:
One of the most important assets owned by a company is human resources because it has an influence on the survival of the company. Employees in a company should be provided with a comfortable working environment to produce optimal performance. The work environment is an important thing to be considered by every company and is one of the factors that determine employee performance. The purposes of this research are to know how is the work environment, employee performance and how much is the impact of work environment to employee performance. This research was conducted by distributing questionnaires to 116 employees at the Division of Part Detail Manufacturing Production Directorate of PT Dirgantara Indonesia (Persero). Based on research that has been done, the regression equation $Y=40404+0,438 X$. The study states the working environment and employee performance in the Department of Part Detail Manufacturing Production Directorate of PT Dirgantara Indonesia (Persero) has a positive relationship (moderate) with a value of 0.438 and the working environment influence on employee performance.
\end{abstract}

Keywords: human resource, work environtment, work performace.

\begin{abstract}
Abstrak:
Salah satu aset terpenting yang dimiliki oleh suatu perusahaan adalah sumber daya manusia karena memiliki pengaruh dalam keberlangsungan hidup perusahaan. Karyawan dalam suatu perusahaan perlu diberikan tempat kerja yang nyaman agar menghasilkan kinerja optimal. Lingkungan kerja merupakan suatu hal yang penting untuk diperhatikan oleh perusahaan dan merupakan salah satu faktor menentukan kinerja karyawan. Tujuan penelitian ini mengetahui bagaimana lingkungan kerja, kinerja karyawan dan pengaruh lingkungan kerja terhadap kinerja karyawan di Divisi Detail Part Manufacturing Direktorat Produksi PT Dirgantara Indonesia (Persero). Penelitian ini dilakukan dengan menyebarkan kuesioner kepada 116 karyawan di Divisi Detail Part Manufacturing Direktorat Produksi PT Dirgantara Indonesia (Persero). Berdasarkan penelitian yang telah dilakukan, diperoleh persamaan regresi $Y=40.404+0,438 X$. Hasil penelitian menyatakan lingkungan kerja dan kinerja karyawan yang ada di Divisi Detail Part Manufactur Direktorat Produksi PT Dirgantara Indonesia (Persero) memiliki hubungan positif yang sedang (moderate) dengan nilai sebesar 0,438 dan lingkungan kerja berpengaruh terhadap kinerja karyawan .
\end{abstract}

Kata kunci: kinerja karyawan, lingkungan kerja, sumber daya manusia.

\section{PENDAHULUAN}

Satu aset terpenting dimiliki oleh

*Email Korespondensi:
Lyta Lestary
Lyta.lestary@gmail.com suatu perusahaan adalah sumber daya manusia karena memiliki pengaruh dalam keberlangsungan hidup perusahaan. Bentuk serta tujuan organisasi dibuat berdasarkan berbagai visi untuk kepentingan manusia,

Jurnal Riset Bisnis \& Investasi 
dalam pelaksanaan misinya dikelola dan diurus oleh manusia. Jadi, manusia merupakan faktor strategis dari semua kegiatan organisasi. Organisasi harus menyadari potensi tenaga kerja mereka karena lingkungan bisnis yang semakin kompetitif. Memiliki kinerja karyawan yang tinggi, akan meningkatkan tingkat produktivitas perusahaan dan dengan demikian akan meningkatkan keuntungan perusahaan.

Berdasarkan penelitian, Naharuddin dan Sadegi (2013) membuktikan kinerja karyawan tergantung pada kemauan dan juga keterbukaan karyawan itu sendiri dengan dirinya dan orang lain dalam melakukan pekerjaannya. Selanjutnya dia menyatakan adanya kemauan dan keterbukaan karyawan dalam menjalankan tugasnya, dapat meningkatkan produktivitas karyawan yang juga berujung pada kinerja.

Kinerja karyawan dipengaruhi oleh banyak faktor, faktor dari dalam dan luar dirinya. Faktor dalam dirinya sendiri adalah pengetahuan, keterampilan dan kompetesi yang dimiliki, motivasi kerja, kepribadian, sikap dan perilaku yang mempunyai pengaruh kinerjanya. Faktor dari luar dirinya antara lain gaya kepemimpinan atasan, hubungan antara para karyawan, lingkungan kerja tempat karyawan bekerja.

Lingkungan kerja merupakan salah satu faktor yang menentukan kinerja karyawan. Kinerja karyawan merupakan salah satu kunci sukses perusahan untuk mencapai kesuksesan. Maka dari itu setiap perusahaan harus memiliki lingkungan kerja yang sesuai bagi kelangsungan kerja karyawan dan meningkatkan kinerja karyawan. Penelitian menyebuktkan bahwa variabel lingkungan kerja mempunyai pengaruh yang sangat signifikan terhadap kinerja karyawan ((Widiasworo, 2014); Jayaweera (2015); (Samson, Waiganjo, \& Koima, 2015); (Malik, Ahmad, Gomez, \& Ali, 2011)).
Lingkungan kerja yang mendukung adalah yang memiliki kemampuan dalam melibatkan karyawan dengan kinerjanya. Penelitian Raziq \& Maulabakhsh (2015) menyebutkan bahwa lingkungan kerja yang baik salah satunya meningkatkan produksi dan kinerja karyawan dimana pada akhirnya akan meningkatkan efektivitas organisasi serta dapat mengurangi biaya yang dikeluarkan oleh perusahaan.

Perusahaan yang akan diteliti mengenai hal ini adalah PT Dirgantara Indonesia (Persero) berlokasi di Kota Bandung. PTDI memiliki salah satu bagian dalam Direktorat Produksi yang bernama Divisi Detail Part Manufacturing yang bertanggung jawab untuk memproduksi beberapa produk pendukung dalam pembuatan komponen pesawat terbang. Berdasarkan hasil observasi yang telah dilakukan tanggal 20 Maret 2017 sampai 23 Maret 2017, keadaan lingkungan kerja yang ada di Divisi Detail Part Manufacturing ini belum mendukung karyawan bekerja dengan nyaman. Hal ini terlihat adannya beberapa permasalahan yang terjadi pertama, kurangnya pencahayaan di beberapa tempat. Kurangnya pencahayaan akan menjadi penyebab utama dalam kualitas dan efisiensi kerja yang buruk. Menurut Sukoco (2006:208) kelelahan pada mata akan meningkat apabila tingkat cahaya di tempat kerja tidak sesuai yang akan mengakibatkan karyawan mengalami ketegangan pada matanya, sehingga mempengaruhi fisiknya. Selain itu, pencahayaan yang kurang mengakibatkan mata menjadi cepat lelah, sehingga mengakibatkan lelahnya mental dan menimbulkan kerusakan mata. Kedua, suhu udara di beberapa bagian tidak sama dengan bagian lain dikarenakan kurangnya jumlah pengatur suhu ruangan. Temperatur atau suhu udara harus diperhatikan karena dapat mempengaruhi suhu tubuh dari karyawan yang sedang bekerja (Badayai, 
2012). Ini menunjukkan bahwa bagaimana panas atau dingin di lingkungan kita benarbenar membuat kita merasakan perbedaannya (Badayai, 2012). Ketiga, terdapat bau yang kurang sedap di beberapa bagian. Udara yang tercemar bisa menggangu kesehatan pribadi pegawai. Udara yang tercemar di lingkungan kerja menyebabkan sakit kepala, mata perih, kelelahan, lekas marah, dan depresi. Keempat, beberapa ventilasi yang tertutup. Sirkulasi udara merupakan salah satu hal yang harus diperhatikan dalam suatu organisasi karena sebagian besar waktu dihabiskan oleh karyawan di dalam area kerjanya. Pertukaran udara sangat menentukan kesegaran fisik karyawan. Kelima, kurangnya alat peredam kebisingan. Kebisingan dari bunyi-bunyian mengganggu ketenangan kerja, merusak pendengaran, dan kesalahan komunikasi. Getaran tersebut dapat menyebabkan terganggunya konsentrasi kerja, mempercepat proses kelelahan dan menyebabkan gangguan anggota tubuh seperti mata, telinga, syarat otot dan lainlain, (Sulistiyadi dalam Priansa \& Garnida, 2015: 129). Jika tidak dilakukan dengan baik maka akan menurunkan tingkat prestasi kerja karyawan.
Berdasarkan Tabel 1, dapat terlihat bahwa dimulai dari bulan Januari 2016 hingga bulan Maret 2016 kehadiran karyawan mengalami penurunan dan pada bulan Juni 2016 hingga bulan September 2016 mengalami penurunan pula dan selalu menurun yang artinya tidak sesuai dengan waktu yang telah ditentukan. Permasalahan yang telah disebutkan diatas harus segera diselesaikan agar tidak menghambat dalam mencapai tujuan perusahaan.

Berdasarkan latar belakang masalah yang telah dijelaskan, dan untuk memberikan arahan dan tujuan yang akan dicapai dalam penelitian ini, maka rumusan masalah dari penelitian ini adalah seberapa besar pengaruh lingkungan kerja terhadap kinerja karyawan di Divisi Detail Part Manufacturing Direktorat Produksi PT Dirgantara Indonesia (Persero).

\section{KAJIAN LITERATUR Lingkungan Kerja}

Lingkungan kerja merupakan suatu tempat yang terdapat sejumlah kelompok dimana di dalamnya terdapat beberapa fasilitas pendukung untuk mencapai tujuan perusahaan sesuai dengan visi dan misi perusahaan (Sedarmayanti, 2013:23).

Tabel 1. Kinerja Karyawan Divisi Detail Part Manufacturing Tahun 2016

\begin{tabular}{|l|l|l|l|l|l|l|l|c|}
\hline \multirow{3}{*}{ Bulan } & \multicolumn{2}{|c|}{ Barang Cacat } & \multicolumn{3}{c|}{ Produksi Barang } & \multicolumn{2}{c|}{ Ketepatan Waktu } & Kehadiran \\
\cline { 2 - 9 } & $\begin{array}{c}\text { Jumlah } \\
\text { Maks }\end{array}$ & Hasil & Target & Hasil & Target & Hasil & Target & Hasil \\
\hline Jan & 83 & 154 & 19.780 & 16.585 & $87 \%$ & $70 \%$ & $95 \%$ & $94,98 \%$ \\
\hline Feb & 75 & 76 & 19.780 & 14.981 & $87 \%$ & $70 \%$ & $95 \%$ & $94,83 \%$ \\
\hline Mar & 72 & 65 & 16.813 & 14.322 & $87 \%$ & $71 \%$ & $95 \%$ & $94,84 \%$ \\
\hline Apr & 117 & 59 & 24.725 & 23.445 & $87 \%$ & $74 \%$ & $95 \%$ & $94,99 \%$ \\
\hline Mei & 94 & 56 & 19.780 & 18.887 & $87 \%$ & $71 \%$ & $95 \%$ & $94,88 \%$ \\
\hline Jun & 127 & 25 & 21.758 & 25.424 & $87 \%$ & $72 \%$ & $95 \%$ & $94,93 \%$ \\
\hline Jul & 103 & 37 & 13.846 & 20.681 & $87 \%$ & $73 \%$ & $95 \%$ & $94,61 \%$ \\
\hline Agt & 96 & 24 & 21.758 & 19.299 & $87 \%$ & $74 \%$ & $95 \%$ & $94,30 \%$ \\
\hline Sept & 108 & 29 & 20.769 & 21.570 & $87 \%$ & $72 \%$ & $95 \%$ & $94,12 \%$ \\
\hline Okt & 100 & 18 & 20.769 & 20.018 & $87 \%$ & $72 \%$ & $95 \%$ & $94,17 \%$ \\
\hline Nov & 91 & 63 & 21.758 & 18.128 & $87 \%$ & $71 \%$ & $95 \%$ & $94,24 \%$ \\
\hline Des & 76 & 32 & 19.780 & 15.280 & $87 \%$ & $72 \%$ & $95 \%$ & $94,24 \%$ \\
\hline Rata - rata & 95 & 53 & $20.109,7$ & $19.051,7$ & $87 \%$ & $71,83 \%$ & $95 \%$ & 9 \\
\hline KET & \multicolumn{2}{|c|}{ Buruk } & & Buruk & & Buruk \\
\hline
\end{tabular}

Sumber: Olahan Penulis (2017) 
Menurut Mangkunegara (2013:105) lingkungan kerja adalah semua aspek fisik kerja, psikologis kerja, dan peraturan kerja yang dapat mempengaruhi kepuasan kerja dan pencapaian produktivitas. Heizer dan Render (2015:467) menjelaskan lingkungan kerja sebagai lingkungan fisik di mana para karyawan bekerja dapat memengaruhi kinerja, keselamatan dan kualitas kehidupan pekerjaan mereka.

\section{Lingkungan Kerja Fisik}

Lingkungan fisik di tempat kerja sangat penting bagi kinerja, kepuasan, hubungan sosial karyawan dan kesehatan karyawan. Lingkungan kerja fisik menurut Sedarmayanti (2013:19) adalah semua keadaan berbentuk fisik yang terdapat di sekitar tempat kerja yang dapat mempengaruhi karyawan baik secara langsung maupun secara tidak langsung.

\section{Lingkungan Kerja Non Fisik}

Lingkungan kerja non fisik adalah keadaan lingkungan kerja karyawan yang berupa suasana kerja yang harmonis dimana terjadi hubungan atau komunikasi antara bawahan dengan atasan atau hubungan vertikal serta hubungan antar sesama karyawan atau hubungan horizontal (Sedarmayanti, 2013:21).

Berdasarkan hasil penelitian dan beberapa ahli, faktor yang mempengaruhi lingkungan kerja fisik yaitu penerangan, temperatur/suhu udara, kelembaban, sirkulasi udara, dan kebisingan

sedangkan faktor lingkungan kerja non fisik adalah suatu faktor yang kondisi hubungan kerja antara atasan dengan bawahan dan antara sesama karyawan yang dapat mempengaruhi suasana kerja dan kinerja karyawan (Robbins (2002); Sedarmayanti (2013); Samson, Waiganjo, \& Koima (2015); Hamid \& Hassan (2015); Nitisemito( 2008)). Berikut adalah penjelasannya,
1. Pencahayaan

Penerangan/cahaya merupakan suatu hal yang penting dan hal utama dalam melakukan kegiatan kerja. Lingkungan kerja tanpa pencahayaan yang baik dan sesuai akan menjadi penyebab utama dalam kualitas dan efisiensi kerja yang buruk. Adapun ciri-ciri penerangan yang baik menurut Robbins (2002) adalah sebagai berikut:
a. Sinar cahaya yang cukup
b. Sinarnya yang tidak berkilau dan menyilaukan
c. Tidak terdapat kontras yang tajam
d. Cahaya yang terang
e. Distribusi cahaya yang merata
f. Warna yang sesuai

2. Suhu Udara

Suhu adalah suatu variabel dimana terdapat perbedaan individual yang besar. Suhu memainkan peran penting dalam lingkungan tempat kerja, terutama bagaimana tubuh manusia mencoba untuk mempertahankan suhu yang ideal. Temperatur atau suhu udara harus diperhatikan karena dapat mempengaruhi suhu tubuh dari karyawan yang sedang bekerja (Badayai, 2012).

Menurut Sukoco (2007:219), temperature ideal yang digunakan pada ruang kantor adalah $23-24^{\circ} \mathrm{C}$ dari temperature di luar ruangan. Suhu udara yang nyaman bagi sebagian besar pekerja adalah sebesar $25,6^{\circ} \mathrm{C}$ dengan nilai kelembaban sebesar $45 \%$ (The Liang Gie dalam Priansa \& Garnida, 2015).

3. Kelembaban

Kelembaban adalah banyaknya jumlah air yang terkandung dalam udara dan dinyatakan dalam bentuk persentase. Kelembaban memiliki hubungan dan dipengaruhi oleh temperatur udara, dan secara bersamasama antara temperatur, kelembaban, kecepatan udara bergerak dan radiasi 
panas dari udara tersebut akan mempengaruhi keadaan tubuh manusia pada saat menerima atau melepaskan panas dari tubuhnya. Berdasarkan Peraturan Menteri Kesehatan No. 1077/Menkes/PER/V/2011, tingkatan kelembaban yang dibutuhkan dalam suatu ruangan adalah sebesar 40\%-60\% $\mathrm{Rh}$.

4. Sirkulasi Udara

Sirkulasi udara merupakan salah satu hal yang harus diperhatikan dalam suatu organisasi karena sebagian besar waktu dihabiskan oleh karyawan di dalam area kerjanya. Pertukaran udara sangat menentukan kesegaran fisik karyawan. Di dalam ruangan kerja diperlukan suatu pertukaran udara yang cukup, apabila didalam ruangan kerja tersebut tidak seimbang antara luas ruangan kerja dengan karyawan yaitu ruangan kerja yang sempit tetapi jumlah karyawan yang cukup banyak (Sedarmayanti, 2013:26).

5. Tingkat Kebisingan

Kebisingan menurut Keputusan Menteri Kesehatan Republik Indonesia Nomor 1405/MENKES/SK/XI/2002 adalah terjadinya bunyi yang tidak dikehendaki sehingga menggangu atau membahayakan kesehatan. Tata cara untuk menghilangkan kebisingan tesebut menurut Keputusan di atas yaitu dengan cara meredam, menyekat, memindahkan, pemeliharaan, penanaman pohon, membuat bukit buatan, dan lain-lain. Berdasarkan peraturan tersebut tingkatan kebisingan dalam Nilai Ambang Batas bagi pekerja dengan durasi kerja harian selama 8 jam adalah sebesr $85 \mathrm{db}$.

6. Hubungan Karyawan dengan Atasan Sikap atasan terhadap bawahan memberikan pengaruh bagi karyawan dalam melaksanakan aktivitasnya sikap yang bersahabat, saling menghormati dan menghargai perlu dalam mencapai tujuan perusahaan. Sikap bersahabat yang diciptakan atasan akan menjadikan karyawan lebih betah untuk bekerja dan dapat menimbulkan semangat kerja bagi karyawan (Nitisemito, 2008:171-173).

7. Hubungan Kerja dengan Sesama Karyawan

Hubungan kerja antar karyawan sangat diperlukan untuk melakukan pekerjaan, terutama bagi karyawan yang bekerja secara kelompok. Apabila terjadi konflik maka akan memperkeruh suasana kerja dan akan menurunkan semangat kerja karyawan. Hubungan kerja yang baik antara karyawan yang satu dengan karyawan yang lainnya maka akan meningkatkan semangat kerja bagi karyawan, di mana mereka saling bekerjasama atau saling membantu dalam menyelesaikan suatu pekerjaan (Nitisemito, 2008:171-173).

\section{Kinerja Karyawan}

Kinerja adalah hasil kerja secara kualitas dan kuantitas yang dicapai oleh seorang karyawan dalam melaksanakan tugasnya sesuai dengan tanggung jawab yang diberikan (Mangkunegara, 2013). Lalu Hasibuan (2013) menambahkan bahwa kinerja adalah suatu hasil yang dicapai oleh seseorang dalam melaksanakan tugas-tugas yang dibebankan kepadanya. Prestasi kerja didefinisikan sebagai pemenuhan tugas atau keterampilan terkait pekerjaan oleh seorang karyawan (Hamid \& Hassan, 2015).

Kinerja karyawan dapat dinilai dengan menggunakan beberapa indikator seperti kualitas kerja karyawan, kuantitas atau pencapaian target yang telah ditentukan, penyelesaian tugas yang telah ditentukan, tanggung jawab karyawan atas pekerjaan yang diberikan, dan bagaimana karyawan memelihara dirinya sendiri (Bernardin dan Russel dalam Sutrisno 
(2010); Simamora (2004); Samson, Waiganjo, \& Koima (2015); Hamid \& Hassan (2015)). Berikut adalah penjelasannya,

Menurut Bernardin dan Russel dalam Sutrisno (2010) menyebutkan bahwa terdapat enam kinerja primer yang dapat digunakan untuk mengukur kinerja, yaitu:

1. Quality, merupakan tingkat sejauh mana proses atau hasil pelaksanaan kegiatan mendekati kesempurnaan atau mendekati tujuan yang diharapkan.

2. Quantity, merupakan jumlah yang dihasilkan, misalnya jumlah rupiah, unit, dan siklus kegiatan yang dilakukan.

3. Cost Effectiveness, merupakan tingkat sejauh sekunder dilakukan studi pustaka dengan mencari mana penggunaan sumber daya organisasi landasan teori yang relevan terhadap penelitian (manusia, keuangan, teknologi, dan material) dimaksimalkan untuk mencapai hasil tertinggi atau pengurangan kerugian dari setiap unit penggunaan sumber daya.

4. Need for Supervision, merupakan tingkat sejauh mana seorang pekerja melaksanakan suatu fungsi pekerjaan tanpa memerlukan pengawasan seorang supervisor untuk mencegah tindakan yang kurang diinginkan.

Simanjuntak dalam Widodo (2015:132) menyebutkan bahwa kinerja dipengaruhi oleh :

1. Kualitas dan kemampuan pegawai, yaitu hal-hal yang berhbungan dengan pendidikan/pelatihan, etos kerja, motivasi kerja, sikap mental, dan kondisi fisik pegawai.

2. Sarana pendukung, yaitu hal yang berhubungan dengan lingkungan kerja dan hal-hal yang berhubungan dengan kesejahteraan pegawai.

3. Supra sarana, yaitu hal-hal yang berhubungan dengan kebijaksanaan pemerintah dan hubungan industrial manajemen.

\section{METODE PENELITIAN Sampel}

Populasi dalam penelitian ini adalah 164 karyawan dan sampelnya adalah 116 karyawan Divisi Detail Part Manufacturing Direktorat Produksi PT Dirgantara Indonesia (Persero).

\section{Analisis Deskriptif}

Dalam melakukan penelitian ini penulis menggunakan penelitian menggunakan metode desktiptif dengan pendekatan kuantitatif. Sugiyono (2014:13) menjelaskan bahwa metode penelitian desktiptif kuantitatif dapat diartikan sebagai metode penelitian yang berlandaskan pada sampel filsafat positivisme, digunakan untuk meneliti pada populasi atau sample tertentu, pengumpulan data menggunakan instrument penelitian, analisis data bersifat kuantitatif/statistik, dengan tujuan untuk menguji hipotesis yang telah dibuat.

\section{Analisis Korelasi}

Menurut Silalahi (2010:96) menyatakan bahwa analisis korelasi adalah metode untuk mengukur derajat kekuatan hubungan antara dua variabel atau lebih, baik hubungan positif atau negatif.

\section{Analisis Regresi}

Menurut Sunjoyo (2012:152) persamaan regresi yaitu formula yang mencari nilai variabel dependen dari nilai variabel independen yang diketahui, koefisien regresi merupakan nilai yang mengukur besarnya pengaruh $\mathrm{X}$ terhadap $\mathrm{Y}$ jika $\mathrm{X}$ dinaikan atau diturunkan.

\section{HASIL DAN PEMBAHASAN Analisis Statistik Deskriptif} Untuk mengukur variabel lingkungan kerja dibutuhkan beberapa 
dimensi yang relevan yaitu penerangan/cahaya, temperatur/suhu, kelembaban, sirkulasi udara, kebisingan, hubungan karyawan dengan atasan dan hubungan haryawan dengan sesama rekan kerja. Berikut adalah hasil analisis deskriptif mengenai variabel lingkungan kerja.

Tabel 2. Hasil Analisis Deskriptif Lingkungan Kerja

\begin{tabular}{|c|c|c|c|c|c|}
\hline \multicolumn{6}{|c|}{ Hasil Analisis Deskriptif Variabel Lingíngan Kerja } \\
\hline & $\mathrm{N}$ & Min & Max & Mean & $\begin{array}{c}\text { Std. } \\
\text { Deriation }\end{array}$ \\
\hline Cahaya & 116 & 1 & 5 & 3.81 & .823 \\
\hline Suhus & 116 & 1 & 5 & 3.11 & 1.065 \\
\hline Kelembaban & 116 & 1 & 5 & 3.22 & 1.030 \\
\hline $\begin{array}{c}\text { Sirkulasi } \\
\text { Udara }\end{array}$ & 116 & 1 & $s$ & 3.07 & $1.13 i$ \\
\hline Kebisingan & 116 & 1 & 5 & 3.24 & .924 \\
\hline $\begin{array}{l}\text { Karyawan } \\
\text { dengan } \\
\text { Atasan }\end{array}$ & 116 & 1 & 5 & 3.56 & .810 \\
\hline $\begin{array}{c}\text { Sesama } \\
\text { Karyawan }\end{array}$ & 116 & 2 & $s$ & 4.10 & .594 \\
\hline $\begin{array}{c}\text { Lingkungan } \\
\text { Keria }\end{array}$ & 116 & 2 & 5 & 3.44 & .657 \\
\hline $\begin{array}{l}\text { Valid N } \\
\text { (listnise) }\end{array}$ & 116 & & & & \\
\hline
\end{tabular}

Sumber: Data Output SPSS (2017)

Tabel 3. Hasil Analisis Deskriptif Kinerja Karyawan

\begin{tabular}{|c|c|c|c|}
\hline \multicolumn{4}{|c|}{ Descriptive Statistics Variabel Kinerja Karyawan } \\
\hline $\mathbf{N}$ & Min & Max & Mean ${ }_{\text {Deviation }}^{\text {Std. }}$ \\
\hline Quality & 2 & 5 & 4.020 .5787 \\
\hline Quantity & 2 & 5 & 3.615 .6195 \\
\hline Timeliness 116 & 2 & 5 & 3.871 .5556 \\
\hline $\begin{array}{l}\text { Cost } \\
\text { Effectivenes } 116 \\
s\end{array}$ & 3 & 5 & 3.943 .5886 \\
\hline $\begin{array}{l}\text { Need for } \\
116 \\
\text { Supervision }\end{array}$ & 2 & 5 & 3.629 .6260 \\
\hline $\begin{array}{l}\text { Kinerja } \\
\text { Karyawan }\end{array}$ & 2 & 5 & 3.816 .48078 \\
\hline $\begin{array}{l}\text { Valid N } \\
\text { (listwise) }\end{array}$ & & & \\
\hline
\end{tabular}

Sumber: Data Output SPSS (2017)

Berdasarkan Tabel 2 diketahui bahwa variabel lingkungan kerja memiliki rata-rata jawaban terendah dengan nilai 2 dan rata-rata jawaban tertinggi dengan nilai 5. Nilai mean dari pertanyaan-pertanyaan diatas adalah sebesar 3.44 dan termasuk dalam interval 3,40-4,20. Maka dapat disimpulkan rata-rata tingkat lingkungan kerja di PTDI baik. Nilai standar deviasi variabel lingkungan kerja adalah sebesar 0.657, memiliki persamaan dengan $19.09 \%$ dari nilai mean. Nilai tersebut berada dibawah $20 \%$, artinya jawaban responden untuk variabel lingkungan kerja cenderung memiliki persepsi yang sama. Dimensi hubungan karyawan dengan sesama rekan kerja mendapatkan nilai mean tertinggi dengan nilai 4.1 dan dimensi sirkulasi udara memiliki nilai mean terendah dengan nilai 3.07. Dari ketujuh dimensi variabel lingkungan kerja terdapat empat dimensi yang berada di bawah nilai mean rata-rata variabel yaitu dimensi temperatur/suhu udara, kelembaban, sirkulasi udara dan kebisingan.

Untuk mengukur variabel kinerja karyawan dibutuhkan beberapa dimensi yang relevan yaitu quality, quantity, timeliness, cost effectiveness dan need for supervision. Berikut adalah hasil analisis deskriptif mengenai variabel lingkungan kerja. Berdasarkan Tabel 3, diketahui bahwa variabel kinerja karyawan memiliki rata-rata jawaban terendah dengan nilai 2 dan rata-rata jawaban tertinggi dengan nilai 5. Nilai mean dari pertanyaan-pertanyaan diatas untuk variabel kinerja karyawan adalah sebesar 3.8155 dan masuk kedalam interval 3,40-4,20. Dapat disimpulkan bahwa rata-rata tingkat kinerja karyawan di PTDI tinggi/baik. Nilai standar deviasi variabel kinerja karyawan adalah sebesar 0.48077, memiliki persamaan dengan $12.60 \%$ dari nilai mean. Karena nilai tersebut berada dibawah $20 \%$, artinya jawaban responden untuk variabel kinerja karyawan cenderung memiliki persepsi yang sama. Dimensi quality mendapatkan nilai mean tertinggi dengan nilai 4.0201 dan 
dimensi quantity memiliki nilai mean terendah dengan nilai 3.6149. Dari kelima dimensi variabel kinerja karyawan terdapat dua dimensi yang berada di bawah nilai mean rata-rata variable yaitu quanity dan need for supervision.

\section{Analisis Korelasi}

Analisis korelasi digunakan untuk mengetahui apakah terdapat hubungan antara lingkungan kerja terhadap kinerja karyawan di Divisi Detail Manufactur Direktorat Produksi PT Dirgantara Indonesia (Persero) serta mengetahui seberapa kuat atau lemah hubungan antara lingkungan kerja terhadap kinerja karyawan.

Tabel 4 Uji Korelasi

\begin{tabular}{|l|l|l|l|}
\hline \multirow{4}{*}{$\begin{array}{l}\text { Lingkungan } \\
\text { Kerja }\end{array}$} & $\begin{array}{l}\text { Pearson } \\
\text { Correlation } \\
\text { Lingku } \\
\text { ngan } \\
\text { Kerja }\end{array}$ & $\begin{array}{c}\text { Kinerja } \\
\text { Karya } \\
\text { wan }\end{array}$ \\
\cline { 2 - 4 } & N & $.438^{* *}$ \\
\hline \multirow{3}{*}{$\begin{array}{l}\text { Kinerja } \\
\text { Karya wan }\end{array}$} & $\begin{array}{l}\text { Pearson } \\
\text { Correlation } \\
\text { Sig. (2-tailed) }\end{array}$ & 116 & 116 \\
\cline { 2 - 4 } & N & 116 & $.438^{* *}$ \\
\hline
\end{tabular}

** Correlation is significant at the 0.01 level (2tailed)

Sumber: Data Output SPSS (2017)

Dapat diketahui dari tabel 4 bahwa nilai korelasi atau $\mathrm{R}$ antara kedua variabel tersebut adalah 0,438. Hal ini menggambarkan bahwa hubungan antara variabel bebas (independent) dan variabel tak bebas (dependent) sebesar 43,8\%. Sehingga dapat disimpulkan bahwa hubungan antara variabel lingkungan kerja (X) dan variabel keputusan kinerja karyawan (Y) memiliki hubungan positif yang sedang (moderate). Hal tersebut memiliki arti jika nilai variabel lingkungan kerja ditingkatkan maka akan meningkatkan nilai variabel lain yaitu variabel kinerja karyawan meskipun peningkatannya termasuk kedalam tingkat yang sedang.

\section{Analisis Regresi}

Menurut Sunjoyo (2012:152) persamaan regresi yaitu formula yang mencari nilai variabel dependen dari nilai variabel independen yang diketahui, koefisien regresi merupakan nilai yang mengukur besarnya pengaruh $\mathrm{X}$ terhadap $\mathrm{Y}$ jika $\mathrm{X}$ dinaikan atau diturunkan.

Tabel 5. Analisis Regresi

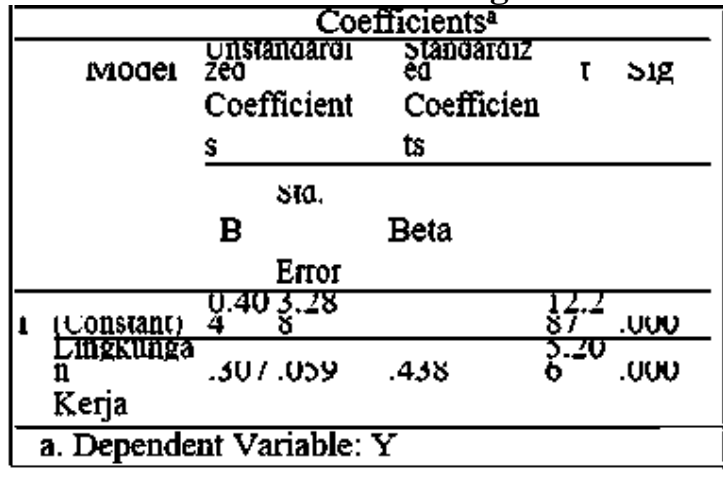

Sumber: Data Output SPSS (2017)

Berdasarkan hasil tabel 5, kita dapat membuat persamaan regresi dengan merujuk pada kolom Unstandardized Coefficients, dimana 40.404

sebagai konstanta (a) dan 0.438 sebagai koefisien regresi (b). Adapun persamaan regresi yang dipakai adalah $\mathrm{Y}=40.404+$ 0,438X. Dimana Y adalah kinerja karyawan dan $\mathrm{X}$ adalah lingkungan kerja. Untuk nilai regresi sederhana, angka korelasinya adalah 0,438 yang merupakan Standard Coefficients (beta). Berdasarkan persamaan tersebut, dapat kita ketahui bahwa Y merupakan kinerja karyawan dan $\mathrm{X}$ adalah lingkungan kerja. Jika perusahaan meningkatkan lingkungan kerja sebesar dengan nilai 1 maka akan mengalami kenaikan sebesar 0,438 yang menyebabkan nilai kinerja menjadi 40.878. Ini artinya jika perusahaan melakukan perubahan lingkungan kerja yang bersifat positif maka kinerja karyawan akan meningkat pula

101 
meskipun dengan peningkatan yang sedang. Sebaliknya jika lingkungan kerja diturunkan maka kinerja karyawan akan menurun.

\section{Pengujian Koefisien Determinasi}

Koefisien determinasi ini digunakan untuk mengetahui seberapa besar kontribusi pengaruh dari lingkungan kerja terhadap kinerja karyawan di Divisi Detail Part Manufacturing Direktorat Produksi PT Dirgantara Indonesia (Persero).

Tabel 6. Koefisien Determinasi

\begin{tabular}{|lllll|}
\hline & \multicolumn{4}{c|}{ Model Summary $^{\mathrm{b}}$} \\
\hline Model & R & R Square & $\begin{array}{l}\text { Adjusted } \\
\text { R Square }\end{array}$ & $\begin{array}{l}\text { Std. Error of } \\
\text { the Estimate }\end{array}$ \\
\hline 1 & $.438^{\mathrm{a}}$ & .192 & .185 & 6.510 \\
\hline
\end{tabular}

Sumber: Data Output SPSS (2017)

Berdasarkan tabel 4.8, angka dalam kolom R Square (koefisien determinasi) yang dihasilkan adalah $0,192(19,2 \%)$ yang merupakan hasil kuadrat dari 0,438. Dalam hal ini berarti 19,2\% kinerja karyawan di PTDI bisa dipengaruhi oleh lingkungan kerja, sedangkan sisanya (100\%$19,2 \%=80,8 \%$ ) disebabkan oleh sebabsebab yang lain yang tidak diketahui dan tidak diteliti dalam penelitian ini.

\section{KESIMPULAN}

Lingkungan kerja Divisi Detail Part Manufacturing Direktorat Produksi PT Dirgantara Indonesia (Persero) sudah baik. Hal ini dapat dilihat dari nilai mean variable lingkungan kerja yang berada dalam skala interval tinggi atau baik.

Kinerja karyawan Divisi Detail Part Manufacturing Direktorat Produksi PT Dirgantara Indonesia (Persero) sudah baik. Hal ini dapat dilihat dari nilai mean variable kinerja karyawan yang berada dalam skala interval tinggi atau baik.

Pengaruh lingkungan kerja terhadap kinerja karyawan pada Divisi Detail Part Manufacturing Direktorat
Produksi PT Dirgantara Indonesia (Persero) adalah sebesar $19,2 \%$ dan sisanya $80,8 \%$ disebabkan oleh sebabsebab yang lain yang tidak diteliti dalam penelitian ini. Berdasarkan hasil ada pengaruh yang positif dari variabel lingkungan kerja terhadap variabel kinerja karyawan. Dapat disimpulkan bahwa lingkungan kerja benar berpengaruh terhadap kinerja karyawan.

\section{DAFTAR PUSTAKA}

Buku

Arikunto, S. (2010). Prosedur Penelitian: Suatu Pendekatan Praktik. Jakarta: Rineka Cipta.

Ghozali, I. (2013). Aplikasi Analisis Multivariate dengan program IBM SPSS 21. Semarang. Badan Penerbit Universitas Diponegoro.

Hasibuan, M. (2013). Manajemen Sumber Daya Manusia. Jakarta: PT.Bumi Aksara.

Heizer, J., \& Render, B. (2015). Manajemen Operasi: Manajemen Keberlangsungan dan Rantai Pasokan. Edisi 11. Jakarta: Penerbit Salemba Empat.

Mangkunegara, A. P. (2013). Manajemen Sumber Daya Manusia Perusahaan. Bandung: Remaja Rosdakarya.

Sedarmayanti. (2013). Manajemen Sumber Daya Manusia. Bandung: Refika.

Silalahi, U. (2010). Metode Penelitian Sosial. Bandung: Refika Aditama.

Sugiama, A. G. (2008). Metode Riset Bisnis dan Manajemen. Bandung: Alfabeta.

Sugiyono. (2012). Metode Penelitian Kuantitatif, Kualitatif dan Kombinasi (Mixed Methods). Bandung: Alfabeta. (2014). Metode Penelitian Kuantitatif, Kualitatif dan $R \& D$. Bandung: Alfabeta. 
Sunjoyo, dkk. (2012). Aplikasi SPSS untuk Smart Riset. Bandung: Alfabeta.

Susetyo, B. (2012). Statistika Untuk Analisis Data Penelitian. Bandung: Refika Aditama.

Taniredja, Tukiran, \& Hidayati M. (2012). Penelitian Kuantitatif (Sebuah Pengantar). Bandung: Alfabeta.

Widodo, S. E. 2015. Manajemen Pengembangan Sumber Daya Manusia. Yogyakarta : Pustaka Belajar.

Umar, H. (2011). Metode Riset Perilaku Organisasi. Jakarta: PT Gramedia

\section{Jurnal}

Hamid, N. A., \& Hassan, N. (2015). The Relationship Between Workplace Environment and Job Performance in Selected Government Offices in Shah Alam, Selangor. International Review of Management and Business Research, 845-851.

Jayaweera, T. (2015). Impact of Work Environtmental Factors on Job Performance: Mediating Role of Work Motivation: A Study of Hotel Sector in England. International Journal of Business and Management, Vol. 10, No. 3, 271278.
Malik, M. I., Ahmad, A., Gomez, S. F., \& Ali, M. (2011, December 28). A Study of Work Environment and Employees' Performance in Pakistan. African Journal of Business Management, 5(34), 13227-13232.

Naharuddin, N. M., \& Sadegi, M. (2013). Factors of Workplace Environment that Affect Employees. International Journal of Independent Research and Studies, 2, 66-78.

Raziq, A., \& Maulabakhsh, R. (2015). Impact of Working Environment on Job Satisfaction. Procedia Economics and Finance 23, 717725.

Samson, G. N., Waiganjo, M., \& Koima, J. (2015). Effect of Workplace Environment on the Performance of Commercial Banks Employees in Nakuru Town. International Journal of Managerial Studies and Research, 76-89.

Widiasworo, L. (2014). Pengaruh Lingkungan Kerja Terhadap Kinerja Karyawan. Universitas Indonesia 